\title{
The European Commission and its legislative activity, not as integrationist and autonomous as believed
}

\author{
Working Paper \\ Author(s): \\ Bailer, Stefanie \\ Publication date: \\ 2006
}

Permanent link:

https://doi.org/10.3929/ethz-a-005389324

Rights / license:

In Copyright - Non-Commercial Use Permitted

Originally published in:

CIS working paper 24(2006) 


\section{uni | eth | zürich \\ Center for Comparative and International Studies (CIS) \\ No 24, 2006}

\section{Working Paper}

Published by the Center for Comparative and International Studies (ETH Zurich and University of Zurich)

\section{The European Commission and Its Legislative Activity - Not as Integrationist and Autonomous as Believed}

by Stefanie Bailer

University of Zurich 


\title{
The European Commission and its legislative activity - not as integrationist and autonomous as believed
}

\author{
by Stefanie Bailer ${ }^{1}$
}

\begin{abstract}
For decades the possible bureaucratic and legislative influence of the European Commission has interested scholars of EU studies (Hooghe 2002; Pollack 1997). Yet, few empirical studies are known about the sources and determinants of influence of the Commission in legislative affairs apart from case studies (Cini 2000; Schmidt 2000).

This paper presents analyses of qualitative and quantitative data to investigate the resources and opportunities leading to the actual legislative success of the Commission. I demonstrate that the influence of the Commission depends on its ability to place a proposal close to the opinion median of the member states, and on external opportunities such as the desire to change the status quo. The Commission's ability to place a proposal close to the opinion median of the Council is dependent on the Commission's expertise and their experience. I conclude that the work of the Commission is far more dependent on the member states than anticipated by neofunctionalists.
\end{abstract}

Keywords: European Commission - international organisation - interinstitutional relations negotiations - principle agent model

\footnotetext{
${ }^{1}$ Stefanie Bailer is post-doctoral researcher and lecturer at the Institute for Political Science at the University of Zurich. Her research interests are decision-making in the European Union, comparative parliamentary politics and the development of civil society in Eastern Europe.
} 


\subsection{Introduction ${ }^{2}$}

When the Council of Ministers and the European Parliament (EP) adopted a very businessfriendly directive on e-commerce trade in the European internal market in 2000, they accepted the original proposal of the European Commission in almost all of its original content ${ }^{3}$. This proposal protected e-commerce businesses from lawsuits by ensuring that the country of origin principle prevailed which meant that the private law of the country of the provider and not the customer is applied in internet transactions. The regulation guarantees that internet traders do not have to adapt to the different legal systems in the member states but that they have only to apply the law of their country of origin. During the discussion of this directive which was subject to the codecision procedure, the Commission could not only defend the main idea of its original proposal against more consumer protectionist member states such as Denmark and Germany, but it could also convince the European Parliament not to force the Council into the conciliation committee but to accept the proposal after the second reading.

Quite contrary to this success story of the influence of the Commission is the discussion about the directive on services in the internal market currently conducted in Brussels. The liberal directive initiated by the former Commissioner Bolkestein in January 2004 intends to remove barriers to trade in services across the European Union (EU). The same idea - "the country of origin principle" - faces now fierce opposition by France and Germany which want to protect their national markets and fear social dumping. The new Commissioner for Internal Market Charlie McCreevy has already backed down and announced that he will reformulate the proposal realising that the current one "will not fly". In its first reading in February 2006 the European Parliament radically changed the content of the directive and it is to be expected that not a lot of its original content will prevail at the end of this codecision procedure.

Both the aforementioned accounts illustrate two views about the influence of the Commission. In the first case the Commission is said to have used its agendasetting right skilfully and thus shaped EU legislation significantly. Other success stories report the adept manipulation of member states' preferences by the Commission before a law was initiated in order to ensure the passing of a law according to the wishes of the Commission (Schmidt 2000). By its sole right to initiative the Commission enjoys a substantial amount of influence on European legislation - a commonly accepted fact which is yet not fully explored. The second case illustrates distinctly that the Commission is dependent on the member states' preferences and has to take them into account in order to realise its policy ideas. The Commission cannot only rely on its preferences such as its information advance and expertise or its legal right to set the agenda, but is also dependent on the relative opportunity structure which the member states provide in the Council. The member states are still the principals of the agent Commission so that their obstruction can distort a proposal to their will.

\footnotetext{
${ }^{2}$ For their helpful comments I would like to thank Peter Selb, Stefanie Walter, the Peergroup "Politikplus" at the University of Zurich and the participants of the workshop "The consequences of Eastern Enlargement in the European Union" held in Berlin, March 2006.
}

3 Information based on interviews conducted by the author in 2000 .

4 Economist, March 12th 2005, p. 36 
In this article, I claim that the European Commission is interested in appearing as a successful player in the EU and does not want to produce proposals which are not taken seriously. Consequently, it proposes laws that have a realistic chance of being adopted by the member states and the European Parliament. In contrast to some authors who claim that the Commission is a preference outlier and proposes extreme ideas, I demonstrate that the Commission positions their proposals close to the dominant opinion of the EU member states. By carefully preparing legislative proposals, the civil servants of the Commission and the Commissioners check whether their proposals are able to pass and find a majority. In the course of the legislative discussions, the Commission is dependent on the partisan preferences of the EU member states and the general desire of the member states to change the status quo. Thus the Commission is still an agent dependent on its principals which can sometimes adeptly use its resources to play out its discretion to full extent.

This article presents in its first part the current state of literature about the influence of the European Commission on European legislation. In the second part I draw my hypotheses about the work of the Commission and show how successful the Commission actually is by analysing these hypotheses with the data set from the research project "Decision Making in the European Union" (DEU). In the final part of the paper I present and discuss the results.

\subsection{Theoretical Background}

The international relations literature has recognized international organisations (IO) as means to overcome market failures, collective action dilemmas, and problems associated with interdependent social choice (Barnett and Finnemore 1999). The reasons why nations delegate power to organisations are founded in the desire to increase power vis-à-vis non member nations. They hope to reduce criticism and opposition from the national constituents because the common action of IOs makes it impossible for voters to compare alternative policies; thus they intend to blur the division of responsibilities between the national and international level (Frey 1997:116; Vaubel 1994).

Both the neoliberal and the neorealist schools of international relations underline the fact, that international organisations help states further their interests, a thought which is also taken up in the intergouvernmentalist research tradition within the EU integration literature (Moravcsik 1993). By reducing transaction costs, increasing efficiency and providing information, EU organs such as the Commission serve as useful tool and arena to the member states in which states realise their policies.

However, neofunctionalists claim that international organisations have developed into actors in their own rights pursuing an agenda and influencing policy outcomes of international cooperation. As a result, they believe that EU organisations independently influence policy outcomes (Sandholtz 1993) and are not "apolitical providers of information" (Garrett 1992:533). Empirical studies of the European Commission support this view to some extent by underlining the independent role which organisations can play (Pollack 1997).

Amongst IOs, the European Commission stands out as an organization having an exception amount of power. The European Commission plays a dominant role in the legislation of the European Union by having the right of legislative initiative and thus determining the 
agenda of the EU and enjoying an information advantage in comparison to its principals ${ }^{5}$. Considering bureaucratic approaches which usually summarize the goals of bureaucrats as achieving a bigger discretionary budget (Niskanen 1971), influencing public policy, power, or career advancement (Tullock 1965) or simply utility (Wintrope 1997:431), I assume that the Commission is interested in influencing EU policy, in deepening further EU integration in order to increase its influence and in appearing successful in order to justify its existence and possible growth.

The Commission has therefore a high interest in maintaining an information advance in comparison to the member states in order to justify its existence and to use this asymmetric information in the legislative negotiation process. Information is the prime reason why politicians delegate authority to bureaucrats (Weber 1921). In its pursuit to acquire and provide information and prepare legislation, bureaucrats enjoy considerable leeway because they are not directly responsible to voters. Bureaucrats in international organisations are said to enjoy even more leeway than officials in national organisations because national actors such as politicians and voters have less to gain by monitoring an international organization (Frey 1997:119). Since the end of the 1990s this has changed to some extent because the scandal around the financial misdemeanour of the Santer Commission and the stepping back of this Collège of Commissioners raised the public awareness of the efficiency and effectiveness of the Commission's activities.

The Commission can control the legislative agenda of the EU by determining the alternatives to be voted upon by the Council and the European Parliament (Wintrope 1997:431). By initiating legislation the Commission definitely influences the timing of legislative proposals whereas its influence on the content is contested. Overall, it is unknown to which extent the original proposals of the Commission get changed by Council and EP. Cini (2000) estimates that up to $80 \%$ of the original proposal remain unchanged, however, this seems to be an informed guess rather than an empirically proven fact. Schmidt (2000) describes two cases in which the Commission used its expert knowledge and strategic skills to manipulate member states preferences or the status quo in order to make use of its agendasetting power. This power can be even more strengthened by timing proposals well. Some skilful Commission officials are said to be able to predict which presidency will treat their proposal favourably and schedule them accordingly. An example for such behaviour is the telecommunication directive which profited greatly from the Italian, Dutch and Belgium presidency (Fouilleux, De Maillard, and Smith 2001).

Part of its agendasetting power is also the power to withdraw a proposal if the Commission considers it to be too distorted by the member states. In one incident Commissioner Bolkestein threatened to withdraw the law on a common customs tariff when he got the impression that the member states were not sufficiently prepared to protect the systems

5 Article 251 und 252 Treaty of the European Communities. For other presentations on the competencies of the Commission see also Nugent

Nugent, N. 2001. The European Commission. Edited by N. Nugent, W. E. Paterson and V. Wright, The European Union Series. Houndmills, Basingstoke: Palgrave., Stevens and Stevens

Stevens, A., and Stevens, H. 2001. Brussels Bureaucrats? The Administration of the European Union. Edited by N. Nugent, William E. Paterson, Vincent Wright, The European Union Series. Houndmills, Basingstoke: Palgrave. or Edwards and Spence

Edwards, G., and Spence, D. 1997. The European Commission. 2nd ed. London: Cartermill.. 
against fraud. The threat showed its desired effect so that the member states complied and adopted the law with a better protection against fraud ${ }^{6}$.

There are several reasons why the agendasetting power of the Commission might be overrated. Firstly, the threat potential to withdraw a proposal is not very credible because the Commission has the reputation of accepting that the Council seriously alters its proposals (Schmidt 2001:126) so that the Commission accepts something more frequently than ending up with nothing.

Secondly, the Council ${ }^{7}$ and the Parliament ${ }^{8}$ have the right to assume part of this right of initiative by asking the Commission to propose a certain law. It is up to the Commission whether to take up these ideas or not, but it generally has the reputation of being very receptive for ideas.

Thirdly, the agendasetting right is influenced by the desire of the Commission to appear as a successful EU organ. The Commission has an interest to justify its existence and thus proposes laws which have a chance of being passed successfully. Therefore, I assume that the European Commission as a rational actor already anticipates possible resistance of the member states and the EP. Hayes-Renshaw and Wallace (1997:186-88) quote an example in which the Commission sent a communication instead of a fully-fledged proposal to the member states in order to test the opinions of the member states and to avoid proposals which would not find a majority in the Council. One of my interview partners described the process as "reality check" in order to control whether some ideas would fly or not. Consequently, I postulate that the Commission uses its informational resources to suggest proposals which take possible resistance of the member states and the EP into account and suggests legislative ideas close to the opinion median of the member state.

This argument is strengthened by Hug's (2003) claim in which he points out that the Commission is not a supranational preference outlier supporting a move towards further integration as often assumed (Garrett and Tsebelis 1996; Smith 2000; Tsebelis 1994). Hug considers it justifiable to assume that the Commission's preferences are not exogenously given but explicable by the preferences of the member states and thus endogenous. Therefore, the preferences of the Commission position relate closely to the preferences of their principals, the member states as Hug (2003:55) demonstrates when analysing the negotiations about the Treaty of Amsterdam.

My main argument concerning the influence of the Commission is that it can use its agendasetting power only to the extent of timing. Regarding the content of its proposals the Commission is very much dependent on the positions of the member states concerning an issue so that it is not wise to suggest ideas that may seem too extreme because the member states can force the Commission to take its proposals back. An example of this is the fate of the very consumer- and environment-friendly directive $\mathrm{REACH}^{9}$, in which former environment Commissioner Wallström intended to have all - and not only newly developed - chemical substances used in the EU tested and registered. Very soon after the introduction of this idea, the governments of France, UK and especially Germany voiced serious opposition to this directive because their respective chemical industries threatened to leave the European markets if such a

6 Agence Europe, Bulletin Quotidien, Nr. 7679, 18.3.2000.

7 Article 208 Treaty establishing the European Community

${ }_{8}^{8}$ Article 192 Treaty establishing the European Community

$9 \mathrm{COM} / 2003 / 644-1$. 
directive would be put into force. The opposition was so intense that Wallström had to revise the proposal already in a very early stage.

This illustrates that the legislators are not completely subject to bureaucratic power but that they are still the principals of the agent "international organisation" (Moe 1997). The Commission has to play the legislative game according to the rules which the member states dictate. The Commission is successful if it uses its informational resources e.g. its staff to estimate the member states' preferences well. Additionally, the legislative success of the Commission is dependent on exogenous variables which the Commission cannot influence such as the attitude of the member states towards the EU.

Derived from the considerations above, I state in my first hypothesis:

H1: The better the Commission predicts the opinion median and the closer it positions its proposal to the opinion median of the Council, the better can the Commission defend its original proposal.

In the further course of legislative negotiations the fate of the Commission's proposal is dependent on the willingness of the EU member states and their attitude towards the EU.

H2: The more EU friendly the member states in the Council are, the better can the Commission defend its original proposal.

Considering the strategic ability of the Commission, I assume that a less cohesive Council offers the possibity to seek strategic allies. Schmidt (2000) elaborated on a case when the European Commission took great care in finding allies for its proposal to liberalize airport services. A similar idea is found in the veto player theory by Tsebelis (2002) when he points out that an increasing distance between two veto players decreases the chances for policy change.

H3: The less cohesive the member states are, the better the Commission can seek strategic allies and therefore defend its original proposal.

The success of the Commission is also dependent on the desire of the member states to change the status quo at all. Romer and Rosenthal (1978) specify that the agendasetting power depends on the reversion level which is what the chooser receives if the agendasetter's suggestion fails. The further the reversion level is from the chooser's ideal point, the greater the agenda-setter's power to get its most preferred outcome. This would mean that the Commission is successful if most member states are distant from the status quo and want to have some policy change or another. This leads to the hypothesis:

H4: The further the member states from the status quo, the the better can the Commission defend its original proposal.

Apart from the member states the Commission has to take into account the European Parliament which has developed into a serious legislative player. The codecision procedure introduced the veto right of the EP after the third reading and a conciliation committee after the second reading in case the Council and the EP do not agree ${ }^{10}$ (Crombez 1996; Rittberger 2000). The Commission is more limited in tabling its proposals as it has to suggest laws which are more attractive than the status quo not only in the eyes of the Council but also in the eyes of the European Parliament (Crombez, Steunenberg, and Corbett 2000). Another power loss to the Commission was introduced in the Treaty of Amsterdam 1994. Since then the Council and the EP decide after the conciliation procedure whether to accept the "joint text" of the conciliation

10 Article 251.5 Treaty establishing the European Communities. 
procedure or whether to dismiss the law. This means a weakening of the influence of the Commission (Crombez, Steunenberg, and Corbett 2000) because the chance increased that EP and Council return to the status quo and no proposal results at all. Earlier, the probability was quite high that the EP would at least accept the "common position" of the Council under the original codecision procedure and that at least a part of the Commission proposal was realised (Kasack 2004).

H5: The closer the Commission's proposal to the European Parliament's position in the codecision procedure, the better can the Commission defend its original proposal.

After having shown that it is beneficial for the Commission to position its proposal close to the opinion median of the Council, I analyse in the second part which resources help the ability of the Commission to find the opinion median of the member states. I claim that this ability is influenced by the Commission's expertise, its experience and its relation to the nation states.

The expertise of the Commission in predicting the positions within the Council is influenced by the respective knowledge in the General-Directorates. Well trained and experienced officials are probably very versed to predict possible resistance amongst the member states' delegations so that this 'bureaucratic resource' can serve as valuable asset of the Commission.

H6: The higher the expertise of the Commission, the better it is in predicting the preferences of the member states and the closer to the opinion median of the member states are its proposals.

Individual Commissioners can make a difference be it due to their charismatic appearance, their diligence, their networks or their political experience. This experience can stem from the fact that they have held high-ranking government positions before they entered the Commission or that they have gathered political experience in other functions previous to their function as Commissioners. If they are not successful, it might be due to a lack of personal resources. Therefore, I state the following hypothesis:

H7: The more experienced the Commissioners who initiate a legislative proposal, the better they are in predicting the preferences of the member states and the closer to the opinion median of the member states are their proposals.

Commissioners can be influenced from the home governments which nominated them. A yet untested assumption is that Commissioners from big countries are always more powerful than their colleagues from small countries because of the weighting of votes in the Council of Ministers (Smith 2003:143). This reflects the idea that Commissioners represent national interests although they are supposed not to. Not all Commissioners manage this "balancing act" (Smith 2003:144), because many Commissioners have an interest in serving those who appointed them. The assumption is also based on the thought that possible tensions and power distributions in the Commission reflect cleavages in the Council.

Furthermore, being from a big member states might provide some latent resources (Smith 2003:153) e.g. bigger informational networks. In contrast, Vaubel (1994) states that Commissioners from small member states with small budgets are more attracted to high positions in the EU Commission in order to gain more discretionary room for political manoeuvres than they would have in their countries. This would imply that Commissioners from small member states have more ambition to be successful than Commissioners from the big member states. Although both arguments are plausible, I am going to state in the next hypothesis that Commissioners from big member states are more influential due to their larger power resources as well as their informational proximity to the power players in the Council. 
H8: The bigger the member states from which the Commissioners stem from, the better the Commissioners are in predicting the preferences of the member states and the closer to the opinion median of the member states are their proposals.

In several instances, it has been known that EU member states have tried to influence EU policies via their Commissioners or that Commissioners have been defending national interests. Considering the fact that amongst budget maximization, a goal of bureaucrats and politicians is career advancement (Tullock 1965), I expect Commissioners to consider their possible future career - maybe in national politics - when initiating legislative proposals. For instance, Spanish Commissioner Loyola de Palacio, responsible for traffic and energy in the Prodi Commission (1999-2004) was once involved in a row over her attempts to influence the EU Fisheries policy in favour of Spanish fishery interests. The attempt of EU member states to influence "their" national Commissioners will be controlled for with the following hypothesis:

H9: The more important a topic for a certain member state, the more extreme is the proposal of the Commissioner from this member state.

\subsection{The data}

I will use two data sets from the research project "Decision Making in the European Union" 11. The first data set on estimates of "Power, Skill and Information" (PSI) of EU institutions and member states was collected by Robert Thomson, Javier Arregui (both at that time

Rijksuniversiteit Groningen) and myself. By interviewing officials from Commission, Council and the EP we wanted to enquire how long-serving officials judge the power of the institutions in contrast to formal analyses and political scientists. Our definition of power included not only formal powers but also informal power such as the formal authority to take decisions, financial resources, information, access to other important stakeholders, and leadership of a large number of people. In sum, we interviewed 21 experts; most of them were chosen because of their longstanding experience in the negotiations between the institutions ${ }^{12}$.

The DEU data set includes detailed information on 66 legislative proposals by the European Commission. The temporal domain of the study is limited insofar as the Council had to discuss a proposal within the period of January 1999 to December 2000. The legislative proposals that were selected were either subject to the consultation or the co-decision procedure; both procedures can require unanimity or qualified majority as voting threshold in the Council of Ministers. The DEU research team conducted 150 expert interviews between early 2000 and early 2002. Interviews were only conducted with experts who had the opportunity to witness the whole bargaining process between and amongst the diverse legislative bodies of the EU.

Firstly, the experts had to identify the controversial issues within a proposal and based on this, they had to indicate the position the decisive actors held shortly before the common

11 Participants of the project were Prof Frans N. Stokman, Dr. Robert Thomson, Javier Arregui (Rijksuniversiteit Groningen), Prof. Bernard Steunenberg, Torsten Selck (Universiteit Leiden), Prof. Ad van Deemen, Vincent Boekhoorn (Katholieke Universiteit Nijmegen), Prof. Madeleine Hösli (Universiteit Leiden), Prof. Gerald Schneider, Prof. Thomas König, Tanja Cornelius (October 1999-June 2000), Stefanie Bailer (University of Konstanz), Prof. Mika Widgrén, Antti Pajala (University of Turku), Prof. Chris Achen (University of Michigan, Ann Arbor). 12 For a more extensive discussion see Thomson Thomson, R. 2002. Estimation of the relative capabilities of the Commission, the Council and the European Parliament using key informants.. 
position was adopted in the Council. Our experts had to locate the two EU actors holding the two most extreme positions on the two end points 0 and 100 of our dimension to represent the stakeholders' opinions on that issue. Intermediate positions taken up by the remaining EU actors represent less extreme positions or compromise solutions achieved in the negotiation. We also asked for the position of the reference point which describes the point prevailing if the negotiators do not find an agreement, as well as the location of the final outcome.

Based on the data of the DEU data set, I calculated the success of the EU actors in the 60 legislative proposals contained in the data as the distance of an actor's ideal position to the outcome. I rescaled this measure by subtracting it from 100 and using the absolute value so that a higher score indicates more success (Hösli 2000).

To measure the influence of the various directorates-general, I inserted the number of staff and the budget size of the responsible DG; these figures which were provided by the European Commission. To measure the ideologies of the Commissioners and the member states, I used the data from the expert survey by Benoit and Laver (2005) who collected data on the European parties' preparedness to shift authority from the national to the EU level using a scale from 1 (favours increasing the range of areas in which the EU can set policy) to 20 (favour reducing the range of areas in which the EU can set policy). Each government represented in the Council at the time when the Commission initiated one of the 60 proposals received a value for its friendliness. For coalition governments, e.g. in Germany, I weighted the values according to the size of coalition parties.

\subsection{Analysis}

In general, the European Commission was regarded by my interview partners as a very powerful player receiving numerical power estimates nearly as high as the Council. The interviewees attributed amazingly high values of 93 and 95 points to the Commission in comparison to the Council at position 100 in both legislative procedures. Considering that the Commission's loses influence in the course of a legislative debate - even more so during the codecision procedure the high values for the Commission amaze. In the last column, I list the average distance of the Commission, the European Parliament and the median of the EU member states' positions to the reference point. At first glance, this reveals that the Commission does seem to have an extreme position far from the status quo; otherwise it would not propose a new piece of legislation. The further analyses will show that the Commission position is not as extreme as it may seem because it is quite oriented towards the member states' preferences.

During the interviews about the power of the EU institutions, my interview partners justified their numerical estimates for the European Commission by especially mentioning the expertise $[8]^{13}$ and the agendasetting power granted by the right of initiative. This was called by one expert "a key role" [4]. A typical comment outlining the traditional source of influence for the Commission was: "[the] Commission has an amazing amount of power since they give the orientation with their suggestions. Strangely enough, the member states do not seem to be able to make compromise suggestions so that they have to rely on the better suggestions of the COM." [5]. One director within the Commission outlined this claim by stating: "When the Commission suggests a proposal on the liberalisation of European electricity market, it is highly improbable

13 The numbers in brackets are identification numbers for the different interview partners who wanted to stay anonymous. 
that there will be no liberalisation whatsoever, so that at least $50 \%$ of the intended objectives of the Commission will prevail" [1].

Table 1 Power estimates and distance to the reference point for the EU institutions ${ }^{14}$.

\begin{tabular}{|c|c|c|c|c|c|}
\hline Actor & $\begin{array}{c}\text { Mean, Standard } \\
\text { Deviation and } n, \\
\text { Consultation Procedure }\end{array}$ & $\begin{array}{l}\text { Standardised } \\
\text { Value, } \\
\text { Consultation }^{15}\end{array}$ & $\begin{array}{l}\text { Mean, Standard } \\
\text { Deviation and n, } \\
\text { Codecision } \\
\text { Procedure }\end{array}$ & $\begin{array}{l}\text { Standardised } \\
\text { Value, } \\
\text { Codecision }^{11}\end{array}$ & $\begin{array}{c}\text { Average } \\
\text { Distance from } \\
\text { the Reference } \\
\text { Point }\end{array}$ \\
\hline \multirow[t]{3}{*}{ Commission } & 91.33 & 93 & 84.66 & 95 & 66 \\
\hline & $(16.5)$ & & (22.58) & & \\
\hline & (15) & & (17) & & \\
\hline \multirow[t]{3}{*}{ Council } & 98.06 & 100 & 89.25 & 100 & 49 \\
\hline & $(4.19)$ & & (15.55) & & \\
\hline & (16) & & (17) & & \\
\hline \multirow[t]{3}{*}{$\mathrm{EP}$} & 27.15 & 28 & 77.53 & 87 & 67 \\
\hline & (17.76) & & (21.06) & & \\
\hline & (16) & & (17) & & \\
\hline
\end{tabular}

A reason leading to such high estimates could be that our interview question did not specify at which time of the legislative procedure the Commission's power had to be estimated. The power of the Commission seems to decline in the course of legislative negotiations, whereas its control over the timing and topic of the legislative debate is highly regarded at. Although the Commission was rated highly, the experts also pointed out that the member states influence the working of this EU organ strongly.

The OLS regression models in table 2 investigate the conditions influencing the ability of the European Commission to defend its original proposal. It shows that the crucial variable for explaining the Commission's success is its ability to position its proposal close to the opinion median of the member states in the Council. Several of my interview partners confirmed this result by pointing out the fact that the Commission does not initiate proposals regardless of the opinions of the member states. The Commission also asks for the opinions of the EU governments before drafting proposals; thus the proposals already reflect opinions of the states and industry. Therefore, one can hardly speak of the Commission as an independent and autonomous actor which develops its preferences independently from the EU nation states. The pharmaceutical industry in particular, is said to have a great influence when it comes to proposing legislation. According to an experienced expert having worked in the Commission for more than 30 years, $30 \%$ of COM proposals are an application of international treaties' obligations, $20 \%$ are suggested by member states and economic actors, $15-20 \%$ are implementations and updates of

\footnotetext{
14 These data are also presented in Thomson

Thomson, R., and Stokman, F. N. 2006. Research Design: Measuring Actors' Positions, Saliences and Capabilities. In The European Union Decides: Political Economy of Institutions and Decisions, edited by R. Thomson, F. N. Stokman, C. H. Achen and T. König. Cambridge: Cambridge University Press.

15 In order to compare the estimates on their original scale, we rescaled the results that the highest value is set to 100 and the other institutions receive the respective values.
} 
already existing legislature or treaty obligations - such as agricultural prices, whereas only $5-10 \%$ are originally new legislative acts [1].

All in all, this specific expert from the Commission estimated that around $90 \%$ of new proposals are already influenced by the member states. Another interview partner pointed out that the Commission is often forced by the member states in package deals to initiate a certain point of legislation: "At least in every Council session, there is one such point on the agenda." [4]. In such package deals the governments are persuaded to agree on a proposal under the condition that the Commission initiates a new idea which entails their objections and ideas leading to their scepticism in the first place.

Table 2: The influence factors on the ability of the Commission to defend its original proposal.

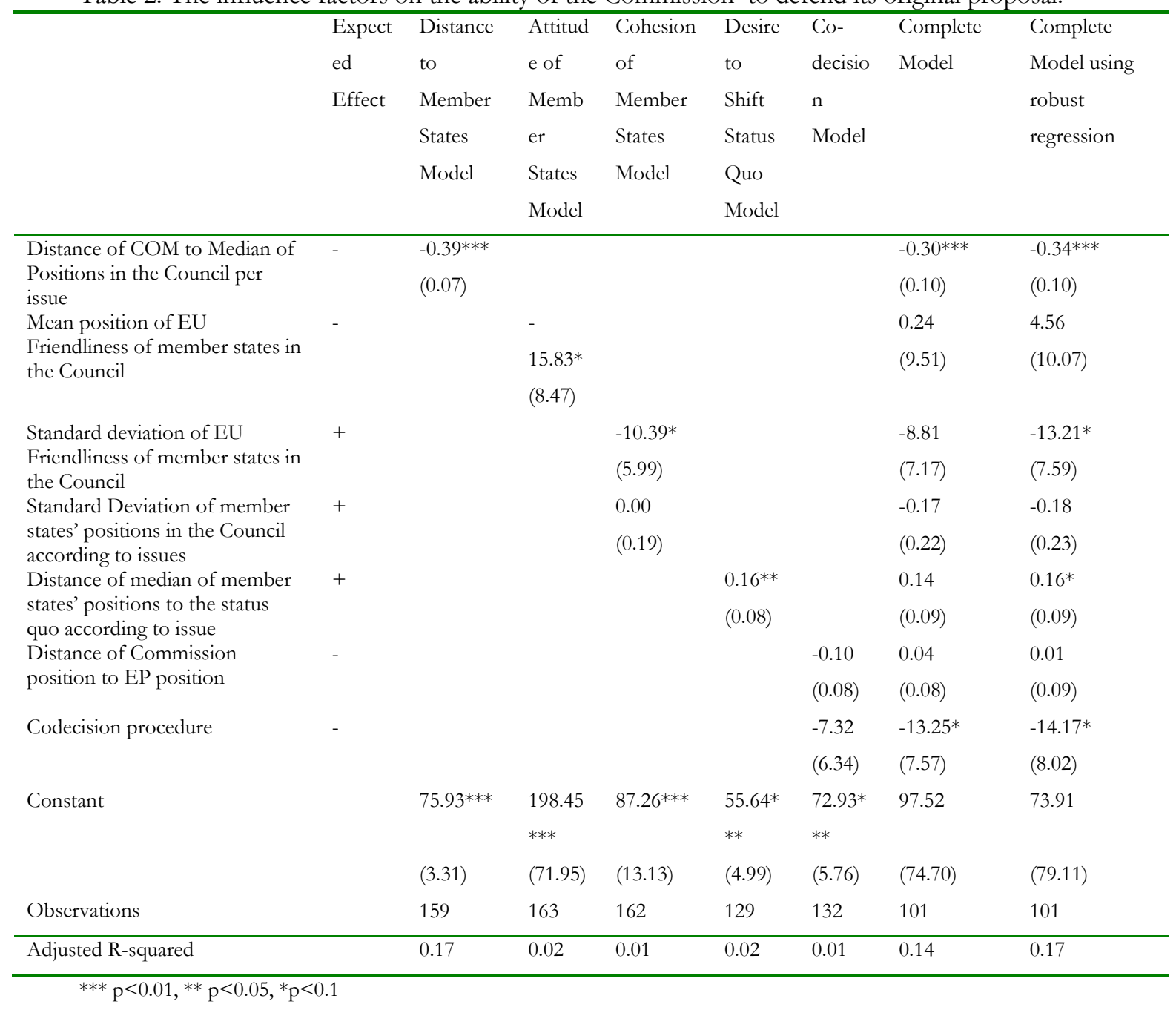

The Commission benefits from an integration-friendly environment in the Council. If the parties represented in the EU governments are against a further EU integration, the ability of the Commission to defend its original proposals sinks. This is a logical result considering that euroskeptical governments are hardly willing to support an EU organ supporting further integration. 
The results concerning the cohesion of the member states are mixed. Measuring the cohesion with the standard deviation of the general attitudes of the member states and the standard deviation of the positions according to issue, I receive an unexpected picture. On the one hand, the negative and significant coefficient of the standard deviation of the general attitudes concerning EU authority indicates that member states which are less cohesive on the question of EU integration decrease the success of the Commission. On the other hand, the more precise measurement of the cohesion in the Council according to negotiation issue poins in the expected direction indicating that the Commission can benefit from strategically searching for alliance partners in the Council. However, this coefficient is not significant. Therefore, the hypothesis concerning the lack of cohesion of the member states benefiting the Commission cannot be confirmed.

The Commission does certainly profit from a shared desire in the Council to change the status quo as the positive and significant outcome of the variable measuring the distance of the Council members to the status quo designates. In a situation when the EU member states prefer to have the status quo changed it is much easier for the supranational bureaucracy to create European law. As a result, the Commision had an easy play during the discussions of the directive on electronic commerce mentioned in the introduction. As one of my interview partners pointed out all EU governments were interested in achieving a new law regulating e-commerce wanting to demonstrate to their constituencies that they are active in an increasingly important policy field.

The expectation that the Commission lost power in the codecision procedure is also justified. Both coefficients - the distance of the Commission position to the EP position and the dummy variable controlling for the codecision procedure show a negative impact on its success. However, only the codecision dummy is significant indicating that the Commission loses around 7 points if it proposes a law under the codecision procedure in comparison to a law under the consultation procedure. One interviewee explained this with: "In the course of the co-decision procedure it [the Commission] becomes more a sort of honest broker, that is a sort of role change. Later on in the course of the co-decision procedure, the power shifts toward the Council and the EP, so that Council and EP have $75 \%$ of the power together, and the COM only $25 \%$." [4].

The two last columns of the table show the complete OLS regression model, the last column controlling for multivariate outliers by using a robust regression meaning that outlying cases get weighted with their absolute residues ${ }^{16}$. In this last model we distinctly see that the ability of the Comission to place its proposal close to the opinion median in the Council is a very relevant factor for its success. However, the Council is still able to block the ideas of the "motor of integration" since its achievement is dependent on the wish of the member states to have legislation at all.

The means which allow the Commission to place its proposal close to the opinion median of the EU member states and the reasons for extreme proposals are analyzed in the

16 I controlled for outlying cases in the other models, too, but in these cases the outliers did not have an impact as high as in the complete model so that I report the OLS regression models only. 
following section. In table 3 I show the results of an OLS regression in which I analyse the influence of the Commission's expertise, experience and the influence of the nation states.

The variable accounting for the size of staff in a General-Directorate measuring bureaucratic expertise shows a significant effect in the expected direction. The more people are dealing with a certain policy area, the better is the Commission equipped to predict the opinions of the member states. In consequence, the European Commission is justified claiming more staff in its regular budget negotiations with the Council and the EP because it seems to be able to translate its staff resource into legislative success. A high staff number in a Directorate-General can also be caused by a number of projects to be administrated as in DG Research which does not necessarily mean that more staff leads to more policy experience.

Table 3: The influence of the resources of the European Commission on the distance of its proposal to the opinion median of the EU member states per negotiation issue

\begin{tabular}{|c|c|c|c|}
\hline & $\begin{array}{l}\text { Expected } \\
\text { Effect }\end{array}$ & $\begin{array}{l}\text { Complete } \\
\text { Model }\end{array}$ & $\begin{array}{l}\text { Complete Robust } \\
\text { Model }\end{array}$ \\
\hline \multirow[t]{2}{*}{ Staff in the initiating DG in 2002} & \multirow[t]{2}{*}{-} & $-0.01 *$ & $-0.01 *$ \\
\hline & & $(0.01)$ & $(0.01)$ \\
\hline \multirow[t]{2}{*}{ Budget of the initiating DG in 2002} & \multirow[t]{2}{*}{-} & 0.00 & 0.00 \\
\hline & & $(0.00)$ & $(0.00)$ \\
\hline \multirow[t]{2}{*}{ Age of the Commissioner } & \multirow[t]{2}{*}{-} & $-2.58 * * *$ & $-2.78^{* * *}$ \\
\hline & & $(0.60)$ & $(0.66)$ \\
\hline \multirow[t]{2}{*}{ Attitude of the Commissioner's party to the EU } & \multirow[t]{2}{*}{-} & 0.53 & 0.13 \\
\hline & & $(1.71)$ & $(1.88)$ \\
\hline \multirow{2}{*}{$\begin{array}{l}\text { Position within the Collège (=Distance of the party of the Commissioner } \\
\text { to the Commission Party Mean on a Left-Right Scale ) }\end{array}$} & \multirow[t]{2}{*}{+} & 0.23 & 0.32 \\
\hline & & $(2.81)$ & $(3.10)$ \\
\hline \multirow[t]{2}{*}{ Dummy controlling for Commissioner Monti } & & 12.83 & 13.63 \\
\hline & & $(12.14)$ & $(13.36)$ \\
\hline \multirow[t]{2}{*}{ Government Experience of Commissioner } & \multirow[t]{2}{*}{-} & $15.62^{*}$ & 17.54 \\
\hline & & $(8.77)$ & $(9.65)$ \\
\hline \multirow[t]{2}{*}{ No of votes of a Commisioner's nation in the Council } & \multirow[t]{2}{*}{-} & $2.81 * *$ & 2.38 \\
\hline & & $(1.33)$ & $(1.47)$ \\
\hline \multirow{2}{*}{$\begin{array}{l}\text { Distance of a Commissioner's home nation from to the position-opinion } \\
\text { mean in the Council (mscommeanrat) }\end{array}$} & \multirow[t]{2}{*}{+} & -0.22 & -0.20 \\
\hline & & $(0.15)$ & $(0.17)$ \\
\hline \multirow[t]{2}{*}{ Salience of a Commissioner's home nation to a certain negotiation issue } & \multirow[t]{2}{*}{+} & $0.29 * *$ & $0.30^{* *}$ \\
\hline & & $(0.13)$ & $(0.15)$ \\
\hline \multirow[t]{2}{*}{ Constant } & & $136.56^{* * *}$ & $150.22^{* * *}$ \\
\hline & & $(32.02)$ & $(35.23)$ \\
\hline Observations & & 142 & 142 \\
\hline Adjusted R-squared & & 0.14 & 0.12 \\
\hline
\end{tabular}


But a high staff number also signifies that this policy area has some importance because its administration or development requires more civil servants; e.g. more than 800 people work in DG Agriculture wheras only 605 people work in DG Employment. The respective budget which is attributed to a DG shows no significant effect and does not help to improve its ability to place a proposal close to the opinion median of the member states.

The variable of the absolute age of a Commissioner serves as a proxy for political experience. Younger Commissioners are better able to place their proposals close to the opinion median of the member states. Maybe younger Commissioners are more interested in placing proposals favourable to the member states, because they are considering to return to national political arenas after their career.

Older Commissioners, however, might be more relaxed about their future career and less ambitious so that they risk proposing more extreme policy ideas be it out of ignorance about the member states' preferences or be it due to fewer worries about their future.

The following two variables account for the partisan preferences of the Commissioners. With the attitude of the Commissioner's party towards the EU, I wanted to test whether Commissioners who belong to parties which opt for a stronger EU integration propose more extreme proposals and are not as closely oriented towards the member states' wishes. The negative coefficient of this variable indicates that this is the case. Those Commissioners, who belong to parties which are sceptical about increasing the power of the EU, initiate laws which are closer to the opinion median of the EU member states and not extremely integrationist. The effect is as expected, yet not significant.

The variable "Position with the Collège" measures the distance of the Commissioners to the Commission Mean on a Left-Right Scale and controls whether the position of a Commissioner within the Collège of Commissioners can explain their proposals. I was expecting a positive influence of this variable because Commissioners in an outsider position within the Collège might rather propose more extreme proposals. The direction of the coefficient is as expected, however the variable does not show a significant effect. I had to control for proposals initiated by Commissioner Monti because Monti does not belong to a party so that I had to impute his missing party data with the average party position of all Commissioners. In order to control for this effect, I inserted a dummy variable for his proposals. It shows that controlling for all other variables Monti generally tended to initiate proposals further from the median than his colleagues.

In my third model accounting for the influence of nation states on the Commissioners, only the salience of a member state from which the Commissioner is originally from explains more extreme proposals. With the dummy variable "Experience from having served in a national government" I was originally trying to measure political experience. The dummy variable demonstrates that a Commissioner who has worked previously in a national government increases the distance of a Commission proposal to the opinion median. I conclude that this variable is rather measuring national influence than experience because a Commissioner's former national position probably enables him to better predict the position of his member state but not necessarily the positions of the other nations. The last recruitment round of the European Commission in 2004, when the big member states were only allowed to send one Commissioner to Brussels, showed that the EU governments know that their Commissioner was a possible instrument for influence. Therefore, most of them sent Commissioners very loyal to their governments and parties, e. g. Mr Verheugen or Mr Mandelson. 
The variable of the size of a Comissioner's home nation is positive but only significant when the regression model is not controlled for multivariate outliers. Commissioners from small member states might more skillful in detecting the opinion median than their colleagues from bigger member states, possibly due to higher ambitions (Vaubel 1994) or because small member states send very high-profile personalities in order to gain profile at the European level. Put it differently, one could also think that the increased weight from being from a bigger member state encourages the Commissioners to be more bold. However, I could not discover this direct translation of national preferences into Commissioner's behaviour. The variable "Distance of a Commissioner's home nation from to the position-opinion mean in the Council"measures whether the home nation of the concerned Commissioner took up an extreme position or not. I was expecting a positive influence in the sense that an extreme position of the home nation could cause an extreme proposal of a Commissioner, but this is not the case.

Then again, if a government shows an increased level of salience towards a negotiation topic, the respective Commissioner tends to more extreme proposals than if it was a topic of average concern to its home nation. This confirms the idea that the Commission is under more pressure from the member states than neofunctionalists would like us to believe.

In conclusion, I found that the better informed the DGs are, the better they are able to identify the opinions of the member states enabling them to propose laws with a high passage probability. Younger, maybe more ambitious Commissioners tend to find the opinion median better than their older colleagues. An influence by the member states on the work of the Commission is notable by the salience coefficient which points out that Commissioners opt for more extreme proposals when their home nations especially care about a certain policy.

Judging these results one could also argue that the resources of the Commission can be directly translated into its ability to defend its original proposal thus supporting the neofunctionalists' idea of the independence and power of this supranational organ. In the appendix in table A2 I show in the complete model of the multivariate regression analysis that some of the Commission's resources actually do have a direct influence on its legislative success. The simple model estimated portrays only the single influence from the variable "Distance of the $\mathrm{COM}$ to the opinion median of the member states" and the coefficient of -0.38 (in contrast to the coeffient of this variable in the complete model of -0.31) shows that a part of the effect of the resources is mediated via the Commission's distance to the member states. Therefore, it is justified to claim that the Commission tries to adjust itself towards the member states' preferences.

\subsection{Conclusion}

This study has shows that the success of the Commission hinges on the willingness of the member states and the ability of the Commission to predict the member states' preferences. With the analyses above I demonstrate that the position of the Commission and therefore its success is not so much determined by its desire to move the status quo in a pro-integrationist direction but by its ability to adapt itself to the opinions of the EU governments. Furthermore, the quantitative results also displayed that the power of the Commission might be overrated by neofunctionalists and some of my interview partners because the positions of the member states has to be taken into account when judging the influence of the European Commission.

The influence of the Commission has additionally suffered from the fact that an increasing percentage of laws are subject to the codecision procedure. If the European 
Constitution will ever enter into force nearly all laws will be subject to the codecision procedure becoming the "ordinary procedure" which will even more reduce the influence of the Commission. The DGs and Commissioners that are able to predict the location of the opinion median of the member states are also more successful in the sense that they have to give up fewer ideas and content of their proposals in the course of the legislative discussions. The European Commission can influence this ability to the extent that it can improve its expertise by a higher number of staff. Nevertheless it stays dependent on the member states because they still seem to influence the Commissioners when negotiation topics are especially dear to them or when the Commissioners are still in a close relationship with their home governments. As conclusion, it has to be noted that the "motor of integration" can only function if its drivers - the EU member states -wish so. 


\section{Appendix}

Table A1 Descriptive Statistics of the dependent and independent variables

\begin{tabular}{|c|c|c|c|c|c|}
\hline Variable & Min & Max & Mean & $\mathrm{Sd}$ & $\mathrm{n}$ \\
\hline $\begin{array}{l}\text { Distance of COM to Median of Positions in the Council per } \\
\text { issue }\end{array}$ & 0 & 100 & 32.13 & 37.06 & 159 \\
\hline Success of the Commission & 0 & 100 & 64.09 & 34.33 & 163 \\
\hline Staff in the initiating DG in 2002 & 89.6 & 2999 & 717.39 & 582.39 & 150 \\
\hline Government Experience of Commissioner & 0 & 1 & 0.62 & 0.49 & 163 \\
\hline No of votes of a Commisioner's nation in the Council & 2 & 10 & 6.92 & 2.96 & 163 \\
\hline Age of the Commissioner & 45 & 69 & 57.61 & 6.03 & 163 \\
\hline $\begin{array}{l}\text { Median position of EU Friendliness of member states in the } \\
\text { Council }\end{array}$ & 8.04 & 8.93 & 8.39 & 0.38 & 163 \\
\hline $\begin{array}{l}\text { Standard Deviation of member states' positions in the } \\
\text { Council according to issues }\end{array}$ & 0 & 54.77 & 31.6 & 15.03 & 162 \\
\hline $\begin{array}{l}\text { Distance of median of member states' positions to the status } \\
\text { quo according to issue }\end{array}$ & 0 & 100 & 52.28 & 36.94 & 129 \\
\hline Distance of Commission position to EP position & 0 & 100 & 35.97 & 38.95 & 132 \\
\hline
\end{tabular}

Table A2 The influence of the resources of the European Commission on its ability to defend its original proposal

\begin{tabular}{|c|c|c|}
\hline & $\begin{array}{l}\text { Complete } \\
\text { Model }\end{array}$ & $\begin{array}{l}\text { Simple } \\
\text { Model }\end{array}$ \\
\hline \multirow[t]{2}{*}{ Distance of COM to Meadian of Positions in the Council per issue } & -0.31 & -0.39 \\
\hline & $(0.08)^{* * *}$ & $(0.07)^{* * *}$ \\
\hline \multirow[t]{2}{*}{ Staff in the initiating DG in 2002} & 0.01 & \\
\hline & $(0.01)^{*}$ & \\
\hline \multirow[t]{2}{*}{ Budget of the initiating DG in 2002} & -0.00 & \\
\hline & $(0.00)$ & \\
\hline \multirow[t]{2}{*}{ Age of the Commissioner } & 0.40 & \\
\hline & $(0.59)$ & \\
\hline \multirow[t]{2}{*}{ Attitude of the Commissioner's party to the EU } & -2.17 & \\
\hline & $(1.57)$ & \\
\hline \multirow{2}{*}{$\begin{array}{l}\text { Position within the Collège (=Distance of the party of the Commissioner to the Commission } \\
\text { Party Mean on a Left-Right Scale ) }\end{array}$} & 3.63 & \\
\hline & $(2.58)$ & \\
\hline \multirow[t]{2}{*}{ Dummy controlling for Commissioner Monti } & 8.77 & \\
\hline & $(11.17)$ & \\
\hline \multirow[t]{2}{*}{ Government Experience of Commissioner } & -14.55 & \\
\hline & $(8.13)^{*}$ & \\
\hline \multirow[t]{2}{*}{ No of votes of a Commisioner's nation in the Council } & -2.15 & \\
\hline & $(1.24)^{*}$ & \\
\hline \multirow{2}{*}{$\begin{array}{l}\text { Distance of a Commissioner's home nation from to the position-opinion mean in the Council } \\
\text { (mscommeanrat) }\end{array}$} & -0.34 & \\
\hline & $(0.14)^{* *}$ & \\
\hline Salience of a Commissioner's home nation to a certain negotiation issue & -0.06 & \\
\hline
\end{tabular}




\begin{tabular}{lll}
\hline Constant & $(0.12)$ & \\
& 85.75 & 75.93 \\
Observations & $(31.30)^{* * *}$ & $(3.31)^{* * *}$ \\
\hline Adjusted R-squared & 142 & 159 \\
\hline
\end{tabular}

\section{Bibliography}

Barnett, M. N., and Finnemore, M. 1999. The Politics, Power, and Pathologies of International Organization. International Organization 53 (4):699-732.

Benoit, K., and Laver, M. 2005. Party Policy in Modern Democracies. London: Routledge.

Cini, M. 2000. Organizational Culture and Reform: The Case of the European Commission und Jacques Santer. Edited by R. S. C. f. A. Studies, European Forum Series RSC 2000/25. Florenz: European University Institute.

Crombez, C. 1996. Legislative Procedures in the European Community. British Journal of Political Science 26 (2):199-228.

Crombez, C., Steunenberg, B., and Corbett, R. 2000. Forum section: Understanding the EU Legislative Process: Codecision: towards a bicameral European Union. European Union Politics 1 (3):365-371.

Edwards, G., and Spence, D. 1997. The European Commission. 2nd ed. London: Cartermill.

Fouilleux, E., De Maillard, J., and Smith, A. 2001. The Role of Council Working Groups in the Production of European Problems and Policies. Paper read at ECSA Annual Conference, 31/52/6, at Madison, Wisconsin.

Frey, B. S. 1997. The public choice of international organizations. In Perspectives on Public Choice. A Handbook, edited by D. C. Mueller. Cambridge: Cambridge University Press.

Garrett, G. 1992. International Cooperation and Institutional Choice: The European Community's Internal Market. International Organization 46:533-.

Garrett, G., and Tsebelis, G. 1996. An Institutional Critique of Intergovernmentalism. International Organization 50 (2):269-299.

Hayes-Renshaw, F., and Wallace, H. 1997. The Council of Ministers. London: Macmillan.

Hooghe, L. 2002. The European Commission and the Integration of Europe. Images of Governance. Cambridge: Cambridge University Press.

Hösli, M. O. 2000. The creation of the European economic and monetary union (EMU): intergovernmental negotiations and two-level games. Journal of European Public Policy 7 (5):744 766.

Hug, S. 2003. Endogenous Preferences and Delegation in the European Union. Comparative Political Studies 36 (1/2):41-74.

Kasack, C. 2004. The legislative impact of the European Parliament under the revised co-decision procedure. European Union Politics 5 (2):241-260. 
Moe, T. M. 1997. The positive theory of public bureaucracy. In Perspectives on Public Choice, edited by D. C. Mueller. Cambridge: Cambridge University Press.

Moravcsik, A. 1993. Preferences and Power in the European Community: A Liberal Intergovernmentalist Approach. Journal of Common Market Studies 31 (4):473-524.

Niskanen, W. A. 1971. Bureaucracy and representative government. Chicago: Aldine Atherton.

Nugent, N. 2001. The European Commission. Edited by N. Nugent, W. E. Paterson and V. Wright, The European Union Series. Houndmills, Basingstoke: Palgrave.

Pollack, M. A. 1997. Delegation, Agency, and Agenda Setting in the European Community. International Organization 51 (1):99-135.

Rittberger, B. 2000. Impatient legislators and new issue-dimensions: a critique of the GarrettTsebelis 'standard version' of legislative politics. Journal of European Public Policy 7 (4):554-575.

Romer, T., and Rosenthal, H. 1978. Political Resource Allocation, Controlled Agendas, and the Status Quo. Public Choice 33:27-43.

Sandholtz, W. 1993. Choosing Union: monetary politics and Maastricht. International Organization 47 (1):1-39.

Schmidt, S. K. 2000. Only an Agenda Setter? The European Commission's Power over the Council of Ministers. European Union Politics 1 (1):37-61.

Schmidt, S. K. 2001. A constrained Commission: informal practices of agenda-setting in the Council. In The rules of integration, edited by G. Schneider and M. Aspinwall. Manchester, New York: Manchester University Press.

Smith, A. 2003. Why European Commissioners Matter. Journal of Common Market Studies 41 (1):137-155.

Smith, M. P. 2000. The European Commission: Diminishing Returns to Entrepreneurship. In The State of the European Union Vol.5, edited by M. G. Cowles and M. Smith.

Stevens, A., and Stevens, H. 2001. Brussels Bureaucrats? The Administration of the European Union. Edited by N. Nugent, William E. Paterson, Vincent Wright, The European Union Series. Houndmills, Basingstoke: Palgrave.

Thomson, R. 2002. Estimation of the relative capabilities of the Commission, the Council and the European Parliament using key informants.

Thomson, R., and Stokman, F. N. 2006. Research Design: Measuring Actors' Positions, Saliences and Capabilities. In The European Union Decides: Political Economy of Institutions and Decisions, edited by R. Thomson, F. N. Stokman, C. H. Achen and T. König. Cambridge: Cambridge University Press.

Tsebelis, G. 1994. The Power of the European Parliament as a Conditional Agenda Setter. American Political Science Review 88 (1):128-844.

Tsebelis, G. 2002. Veto Players. How Political Institutions Work. Princeton: Princeton University Press.

Tullock, G. 1965. The Politics of Bureaucracy. Washington: Public Affairs Press.

Vaubel, R. 1994. The public choice analysis of European integration: A survey. European Journal of Political Economy 10:227-249. 
Weber, M. 1921. Wirtschaft und Gesellschaft: Grundriß der verstehenden Soziologie. Tübingen: J.C.B. Mohr.

Wintrope, R. 1997. Modern bureaucratic theory. In Perspectives on Public Choice. A Handbook, edited by D. C. Mueller. Cambridge: Cambridge University Press. 